\title{
Researching the Past is a Foreign Country: Cognitive Dissonance as a response by practitioner Pagans to academic research on the history of Pagan religions.
}

Modern Paganism is a new religious movement with a strong attachment to the past. Looking back through time to an often idealised ancient world, Pagans frequently seek inspiration, validation and authorisation for present beliefs and activities, as espoused in the familiar catchcries of "tradition", "lineage" and "historical authenticity". A movement that consciously looks to the past and claims to revive the ancient religious practices of pre-Christian Europe, modern Paganism has always been dependent upon academic scholarship_particularly history, archaeology and anthropology — in its project of self-fashioning.

This paper proposes that trying to understand academic research in history and archaeology is, for many modern Pagans, akin to visiting a foreign country where the inhabitants speak an indecipherable language. It argues that the new interdisciplinary category of Pagan Studies scholar - hybrid offspring of the academy and Paganism — is uniquely suited to bridge this communication gap. Utilising the theory of Cognitive Dissonance, this paper will highlight examples of combative interaction between Pagans and academic researchers at three types of site-as-stage: the text, the archaeological excavation, and the museum. It will show that in each case, while concessions may be made on either side, the performers actually fail to communicate. The paper will then explain how the Pagan Studies scholar can act as a "go-between", connecting academia and Pagan practitioners, leading to the conclusion that the Pagan Studies scholar can function to both defuse antagonism, and introduce hybrid vigour into modern Paganism.

A large proportion of Pagans today are unaware of the sources of their religion and do not tend to delve particularly deeply into its origins. Consequently, when they become aware of new academic scholarship — particularly in history and archaeology — which challenges the old scholarship their religion is based on, they can react negatively, perceiving it as threatening to their structure of beliefs and sense of identity. All but a small minority of Pagans resist the findings of such scholarship and cope with its revelations in various ways: one of which involves attempting to inflict the subsequent trauma they feel back on to the academic researchers - the bearers of bad news.

I suggest that this negative reaction is the result of cognitive dissonance, a term coined by psychologist, Leon Festinger, who in 1956 tested his idea that human beings do not like inconsistency by studying the reaction to prophecy disconfirmation by a doomsday cult that believed they were in communication with aliens. ${ }^{1}$ The theory of cognitive dissonance proposes that people have a motivational drive to reduce dissonance which is aroused when they are confronted with information that is inconsistent with their beliefs. If it is not reduced by changing one's belief, dissonance can result in misperception, rejection or refutation of the information, seeking support from others who share the beliefs, and attempting to persuade

\footnotetext{
${ }^{1}$ Cooper, John. Cognitive Dissonance: Fifty years of a Classic Theory. Los Angeles: Sage Publications, 2007. 3-5.
} 
others, in order to restore consonance. It is in an effort to reduce dissonance that these Pagans resort to denial, justification, accusations of anti-Pagan prejudice, and indulgence in confirmation bias: the favouring of information that confirms their preconceptions, regardless of whether it is true - or as archaeologist Brian Hayden describes it, "feel good epistemology."

Current research into the ancient world threatens what many Pagans have both intellectually and emotionally internalised about their religion — what they concretely believe - and this causes the trauma of cognitive dissonance. Aporia looms and the question arises "Am I believing a lie?" Once dissonance is aroused it needs to be reduced and, although one of the options to reduce dissonance would be to be more open to the findings of historical research and therefore modify one's beliefs about Paganism's historicity, the more common reaction seems to be the psychologically comfortable answer: "No" - it is not Paganism that is historically inauthentic; it is the scholars researching it that must be wrong/faulty/anti-pagan. In this case dissonance is not reduced by changing one's beliefs but instead by rejection and refutation of the offensive information, the seeking of support from others who share their beliefs, and the attempt to persuade others of their rightness.

From the Pagan point of view, academics are seen as having colonised what is rightly Pagan as a study topic for themselves. The perception of academics as outsiders has resulted in fierce boundary-policing by Pagans and resistance is framed in terms of protecting religious rights and the expression of outrage at what are perceived as offensive interpretations of a past that Pagans imagine is their own. Essentially it is fundamentalism and stems from fear of removal of a carefully constructed Pagan identity. What Pagans either do not know, or conveniently forget however, is that this identity relied on academic scholarship in the first place.

As we know, such a view of the academic as outsider is actually false when it comes to Pagan Studies scholars, researchers who study Paganism from within disciplines such as anthropology, sociology, religious studies, theology, history and archaeology. Many Pagan Studies scholars are Pagan themselves, with years of involvement within the scene-length of association being one of the hallmarks of authenticity and authority within Paganism. Others are not Pagan, but study communities of practitioners in an ethnographic capacity, respectfully, with an acute awareness of reactivity and reflexivity, and in some cases can claim several decades of involvement. Such longevity surely qualifies these scholars as knowledgeable insiders rather than uninformed "hackademics".

While professional scholars may enter Paganism, most Pagans do not tend to take on academics on their territory. When a situation arises in which Pagans do not like what they hear from academics, the conceptual spaces from which they can speak and be heard, and from where they produce their own counter-narratives, are primarily the internet, self-publishing and the Pagan conference. Particularly in the case of the internet, the material Pagans produce ends up being more widely distributed and easily accessible than academic texts can ever hope to be. It is at these sorts of sites that some Pagans have assumed the discourse of oppressing the perceived 
academic coloniser. A recent example that we would all be familiar with is the vitriol generated as a consequence of the criticism by two academic bloggers, Peg Aloi and Chas Clifton, of Ben Whitmore's book Trials of the Moon.

This is part of a larger situation whereby Pagans who dislike British Historian Ronald Hutton's book, The Triumph of the Moon, have participated in an internet smear campaign against him, motivated by Whitmore's attempted criticism of Hutton's work. While the dependence of modern Witchcraft on late nineteenth and early twentieth century scholarship has been evident to scholars for decades, it appears to have only been grasped by the majority of Pagans themselves in the wake of the 1999 publication of Triumph of the Moon. As we know, Wicca's foundation claim used to correlate with historical research, but the supportive scholarly interpretation of witchcraft popularised by Margaret Murray was discredited in the 1970s. It is obvious that many Pagans, including those that so vehemently oppose Hutton's work, are unaware of the evolution of witchcraft scholarship. Nor do they understand the rigors of historical methodology, and that Whitmore's book has, in fact, not in any way demolished Hutton's research. Anti-Huttonists have gleefully lionised Whitmore, seeing him as a noble "man of the people" defeating the assault by malevolent academics such as Hutton who obviously have the destruction of the Wiccan religion in mind.

A simple internet search reveals that-despite Hutton's recent article on Witchcraft historiography and Peg Aloi's review of Whitmore's book, published in The Pomegranate, and which are both freely accessible on the internet-Whitmore's Trials of the Moon is thought to have vindicated the Murrayite standpoint and he has been made a hero, fans of his work not understanding that pointing out a few mistakes or omissions does not a successful refutation make. In comments on internet discussion boards, fans of Whitmore freely admit that they cannot tell whether his observations are correct. The important thing is that they seem correct, they claim to take down Hutton, and that feels good so it must be right. Carla O'Harris sums up this attitude with her vitriolic comment on Chas Clifton's blog: "Hutton is a second-rate hackartist whose cult is completely undeserving."

Archaeological examples in which Pagans clash with academics are probably better known than textual ones. Perhaps the most familiar case would be that of Goddess worshippers at the Neolithic Anatolian site of Çatalhöyük in Turkey. Goddess Pagans identify prehistoric female figurines as "aspects" of the "Great Goddess" and believe they provide evidence for the existence of a utopian world in which women were not subject to oppression-despite the many criticisms of this interpretation for figurines and the fact that the presence of goddesses in a society does not equate to a high status for human women. Inspiration comes from the midtwentieth century interpretation of the site by its first excavator, James Mellaart, and later popularised by archaeologist Marija Gimbutas. New excavations, directed by Ian Hodder of Stanford University, begun at the site in 1993, do not tend to confirm the Great Goddess theory, and attempt a more nuanced interpretation of the figurines, decorated houses and human skeletons that Mellaart had described as goddesses, shrines and priestesses. Goddess 
Worshippers, who visit the site regularly, express confusion as to why the current excavators will not accept Mellaart's view of the site, which has become for them an article of faith, accusing them of bias, blindness, and patriarchal conspiracy. The director has even received death threats.

Anthropologist Katherine Rountree has studied the interaction between archaeologists and goddess worshippers at Çatalhöyük and highlighted the ways in which the project's alleged multivocal interpretative process privileges the archaeologists' views while the goddess worshippers' opinions take a back seat. From an archaeologists point of view however, while members of the Goddess Community may have interesting opinions, and even academic credentials, they tend not to be trained in archaeology and subsequently do not understand that the unwillingness of the archaeologists to incorporate their views is not because of a conspiracy against women, but because they are simply archaeologically unconvincing.

In the UK certain varieties of Pagan Druid contest the interpretation of archaeological sites, in addition to campaigning for reburial of human remains and privileged access to museum collections. Inspired by the South Australian Aboriginal Heritage Act of 1988 and the Native American Graves Protection and Repatriation Act of 1990, these Druids situate themselves as "indigenous" and demand consideration by archaeological, heritage and museum bodies even though, unlike indigenous groups in the United States or Australia, they cannot demonstrate any linage other than an imaginative one to archaeological sites or artefacts. At Seahenge in Norfolk, in 1999, Druids were amongst other groups including New Agers and Eco-warriors, who disrupted and attempted to thwart archaeological excavation at the site, claiming to spiritually own it. In 2007 Druids agitated for a Neolithic skeleton, held in the Alexander Keiller Museum in Wiltshire, to be reburied, claiming it was their ancestor.

Another Druid group, Honouring the Ancient Dead (HAD) ${ }^{2}$ are specifically focussed upon both the reburial of ancient human remains as well as enabling special access for Pagans to certain ancient objects held in museums. ${ }^{3}$ There are many such projects on HAD's website and a letter in Museum Archaeologists News claims that HAD have their sights set on 135 collecting institutions in the UK which it plans to contact in regards to having input into their housing of human remains. Facilitated by the current climate of deference to faith groups in Britain, HAD have been successful at brokering deals between Druids and museum curators and public relations departments, a particularly outstanding occasion being in 2005-6 when they obtained privileged access to the Babylonian plaque, "The Queen of the Night"- despite the fact that their

\footnotetext{
${ }^{2}$ Orr, Emma Restall. "Consultation on the Request for Reburial of Human Remains, Avebury, Wiltshire February 2009.” Museum Archaeologists News 46. (Spring 2009): 1-2.

${ }^{3}$ Blain, Jenny and Wallis, Robert. Sacred Sites Contested Rites/Rights: Pagan Engagements with Archaeological Monuments. (Eastbourne. Sussex Academic Press. 2007). 190. The precedent being in 1996 in the USA with 'Kennewick Man' where both Native Americans and local Pagans, members of the Asatru Folk Assembly, were granted access to the remains to perform ceremonies while scientific analyses and by the physical anthropologists was halted. http://en.wikipedia.org/wiki/Asatru_Folk_Assembly [28/1/09].
} 
website shows that they do not have a clue about its origin, describing it as "Stone Age" and "Druid".

One might ask at this point, "What's the harm here? Does it really matter what Pagans think about the past? How is it anyone's business? I think however, that the promotion of pseudoscholarship should be the concern of academics in the affected fields. Pagan opinion is influential because of the heavy reliance on the internet with its disseminatory power, as well as the self-publishing boom. In the case of witchcraft history, by casting aspersions on contemporary - and better - research, Pagans perpetuate the circulation of outdated scholarship and keep the public in thrall to false histories. With the Goddess Movement, it is evident that participants do not understand why evidence should not be fitted into a preconceived pet theory and that during their close dealings with archaeologists at Çatalhöyük, this basic tenet of archaeology has not been successfully communicated. Nor is the situation regarding special museum access for Pagans in Britain a good thing, because such politically-correct public relations by museums is not helping educate anyone in real history. Researching the past is still a foreign country to Pagans. Academics and Pagans are still polarised, even though in some cases there is the appearance of respect and consensus.

Rountree has said repeatedly that scholars and practitioners are "talking past each other" and that they even "speak different languages". ${ }^{4}$ In the case of the critique of Whitmore's book it became evident that academics and Pagans were actually shouting at each other-or, more accurately, academics were being shouted at! As I have suggested, it is cognitive dissonance that is causing Pagans to shout, and that this is a reaction to two factors: not liking what they hear and not understanding why the academic researcher is saying it. I think the solution is for academics to make more effort to communicate the reasons why — in cases of contentious research — what they are saying is being said.

Foucault argues that the role of the historian should be to demystify the claims to knowledge made by the powerful and to support those who are oppressed by it. The communication of academic research methodologies is not about beating Pagans over the head with new scholarship, or performing academic oppression of the non-academically literate "other", but about explaining contentious research results, the components of the investigative methods behind them, and how they lead to certain conclusions and not others. Nor is this, essentially transcultural, communication an attempt by outsider academics to colonise the minds of Pagans, as Pagan Studies scholars are already insiders. It is simply a method for diffusing antagonism through education. Pagans are free to continue to dislike and even ignore what they hear in regards to the findings of scholarship, but they cannot continue to enforce the exclusion of new academic research from Paganism. As insiders, Paganism belongs to Pagan Studies scholars too.

\footnotetext{
${ }^{4}$ Rountree, Kathryn. "Talking Past Each Other: Practising Multivocality at Çatalhöyük.” Journal of Archaeomythology 3:1 (2007) p.45.
} 
Because they are insiders, straddling the academic-practitioner divide and speaking both languages, Pagan Studies scholars are uniquely situated to defuse the antipathy between Pagans and academics. They already have ample experience translating Paganism into "academese" and are thus familiar with the role of intercultural performer. It is simply a matter of reversing the flow of information. As I have suggested, along with not liking what they hear, Pagan aggression also stems from not actually understanding academic language, both in its written form as well as in regards to theoretical reasoning and conceptual structures. Pagan Studies scholars can act as translators, explaining and guiding practitioners into the mysteries of academic thinking by decoding the findings of scholarly research, the methods of acquisition of such knowledge, and the reasons for particular standards of evidence to be required. They can also help Pagans keep up with current research, a near impossible task without university access to academic journals.

While the results of scholarship can, theoretically, be accessed by Pagans in the form of published texts, it is the methodologies of such research that need to be clarified. When it comes to history and archaeology, not all ideas about the past are equal, some descriptions of the human past are more likely than others to be accurate and so there is more reason to believe some than others - even if none is perfectly justified to the point of certainty. It is important to explain that there are ways to distinguish plausible from implausible theories about the past; the criteria of credible, meaningful evidence; that standards of justification exist; and that there is a correlation between a theory being more justified by the evidence and it being more likely to be accurate. It is not so much the answers to questions about the past that are the concern, but the ability to distinguish evidence from belief, opinion, dogma, or wishful thinking.

I need to emphasise that I am not suggesting that that knowledge gained through the currently valid procedures of the human sciences is necessarily superior to knowledge gained in other ways, such as those methods used by many modern Pagans such as dreams, trance states, gut knowing, flashes of intuition or revelation. Obviously different intellectual and political movments create their own forms of relative 'knowledge', truth is a relative rather than an absolute concept, and what is 'true' depends on who is speaking to whom and in what context. If this is the case though, then academic research ought to be afforded the same respect as these 'other' forms of knowledge. Through more in-depth explanation of the methods utilised within academic research, aporetic inconsistency experienced by Pagans can be managed in a less confrontational manner.

Postmodernism rightly problematises claims to "truth"; however within the antagonistic situation between academics and Pagans, this has worked to the detriment of the incorporation of knowledge from disciplines that study the past—such as history and archaeology —into Paganism, and within Paganism has privileged religious stasis over dynamism. Pagans risk being stereotyped as "Nobel Savages". This is patronising to those Pagans who do welcome the results of academic research and, instead of building bridges, creates barriers to real communication between scholars and Pagans. Not all Pagans want to fossilise in a pseudo-primitivist mental utopia. 
Pagan Studies scholars have the capability to invigorate Paganism from within. By inhabiting the grey area between ivory tower academia and on-the-ground Pagan practitioners, the Pagan Studies scholar is a go-between, a translator, but not a proselytiser. The hybrid nature of the Pagan Studies scholar can work to reduce dissonance and hence trauma and aggression, diffusing black-and-white antagonistic, combative positions and facilitating reconciliation. A religion that is static is dead. The Pagan Studies scholar infuses Paganism with hybrid vigour and can enable Pagan practitioners to perceive academic research, not as a repressive ideology, but a liberating one. Such hybridity does not shut down multivocalism but contributes to polyphonic discourse within contemporary Paganism. 


\section{University Library}

\section{- M M N E R VA A gateway to Melbourne's research publications}

Minerva Access is the Institutional Repository of The University of Melbourne

Author/s:

Tully, CJ

Title:

Researching the Past is a Foreign Country: Cognitive Dissonance as a Response by Practitioner Pagans to Academic Research on the History of Pagan Religions

Date:

2011-01-01

\section{Citation:}

Tully, C. J. (2011). Researching the Past is a Foreign Country: Cognitive Dissonance as a Response by Practitioner Pagans to Academic Research on the History of Pagan Religions. The Pomegranate: the international journal of Pagan studies, 13 (1), pp.98-105. https:// doi.org/10.1558/pome.v13i1.98.

Persistent Link:

http://hdl.handle.net/11343/252810 